Pak. j. sci. ind. res. Ser. B: biol. sci. 201154 (2) 106-110

\title{
Effect of Bran Roasting Temperature and Time on Yield and Quality Attributes of Rice Bran Oil
}

\author{
James Abiodun Adeyanju ${ }^{\mathrm{a} *}$, Rahman Akinoso ${ }^{\mathrm{b}}$ and Emmanuel Adedapo Akande ${ }^{\mathrm{a}}$ \\ ${ }^{\mathrm{a}}$ Department of Food Science and Engineering, Ladoke Akintola, University of Technology, \\ LAUTECH, Ogbomoso, Nigeria \\ ${ }^{\mathbf{b}}$ Department of Food Technology, University of Ibadan, Ibadan, Nigeria \\ (received December 1, 2010; revised April 4, 2011; accepted May 3, 2011)
}

\begin{abstract}
The effects of bran roasting temperature (160-200) ${ }^{\circ} \mathrm{C}$ and time (5-35 min) on the yield and quality attributes of 'Ofada' rice bran oil were studied so as to optimize the processing conditions for maximum oil yield with least deterioration of qualities. The physico-chemical parameters of oil studied included: yield, free fatty acids, peroxide value and colour, which were recorded as $14.50 \%, 5.80 \%$ (as oleic), $8.25 \mathrm{meq} / \mathrm{kg}$ and $1.51 \mathrm{abs}$, respectively. The optimum conditions were $200{ }^{\circ} \mathrm{C}$ roasting temperature and 15 min roasting time. With increasing the roasting temperature from $160-200{ }^{\circ} \mathrm{C}$ and the time $5-35$ min, the oil yield and colour increased $11.31-14.50 \%$ and $1.51-1.58$ abs, respectively, while free fatty acid and peroxide values decreased from $12.75-5.80 \%$ and $13.75-8.25 \mathrm{meq} / \mathrm{kg}$, respectively.
\end{abstract}

Keywords: rice bran, roasting time, roasting temperature, rice bran oil

\section{Introduction}

Rice bran is the major by-product of rice milling process accounting for about $8.0 \%$ of the milled rice (Sereewatthanawut et al., 2008). Its production is about 50-60 million tons per year which is normally used as animal feed (Devi and Arumughan, 2007). This biomass is a natural source of oil, carbohydrates, proteins, vitamins, antioxidants, enzymes, dietary fibres (Luh, et al. 1991; Saunders, 1986).

Depending on milling procedure, rice bran contain $10.0-26.0 \%$ oil, hence this abundant biomass has considerable potential of fulfilling the global oil requirements (Prabhakar and Venkatesh, 1986). According to Yoshida et al. (1999) the bran contains about $18 \%$ edible oil, which has a unique complex of naturally occurring antioxidant components. Rice bran oil has vast applications in different industries (Zullaikah et al., 2005; Luh, 1980), low level of saturated fat (Hargrove, 1994) and cholesterol lowering activity in humans (Most et al., 2005). Its unique properties make it very appealing to food and pharmaceutical companies (Devi and Arumughan, 2007; McCaskill and Zhang, 1999). However, only a small portion $(<10.0 \%)$ of rice bran oil is processed into edible oil (Zullaikah et al., 2005). The reason is the free fatty acids which are produced as a result of hydrolysis making rice bran

*Author for correspondence; E-mail: biodunjames24@yahoo.com oil unfit for edible purposes (Goffman et al., 2003; Westphal et al., 2002). Generally, rice bran oil with an excess of $10.0 \%$ free fatty acids is unfit for human consumption ( Tao et al., 1993; Enochian et al., 1981). Rice is a major source of inorganic arsenic (As), a non-threshold class 1 carcinogen.

Sun et al., (2008) reported that rice bran and rice bran solubles contain inorganic arsenic levels of around $1 \mathrm{mg} / \mathrm{kg}$ dry weight, which is around 10-20 times the concentration found in bulk grain. Reducing the amount of total and inorganic As in the rice grain would reduce the exposure risk.

Recently, rice bran oil has been used in some developed countries as condiment oil along with sesame oil and perilla. Traditionally, these condiment seed oils are extracted using mechanical press or through solvent extraction after roasting of the seeds at appropriate temperature, for appropriate length of time. During roasting or cooking process, a pleasant aroma or taste (nutlike or peanut butter-like) develops in the seeds which gets transfered to the oil during extraction. The amount of extractable oil depends on the variety of rice bran, extraction conditions, addition of entrainer and milling procedure.

Rice bran is commercially utilized as supplement for animal feed with less attention on extraction of the oil content. Research into the potential of rice bran 
as a source of edible oil is desirable. Information on degree of influence of various parameters on quantity and quality attributes of oil recovered from rice bran is liable to increase the value of rice bran for use in the third world countries.

The objectives of this study were to observe the effects of various roasting temperature and time on the oil yield, free fatty acids, peroxide values, and colour of locally produced 'ofada' rice bran oil so as to establish optimum extraction parameters.

\section{Materials and Methods}

Materials. Rice bran used in this study was obtained from Fortune Agricultural Services Limited, Ibadan, Oyo State, Nigeria.

Methods. The samples of parboiled rice bran were cleaned manually to remove all foreign matter such as dust, dirt, stones and broken grains that can influence the oil yield and quality of extracted rice bran oil . All chemicals used were of analytical grade.

Preparation of rice bran oil. Rice bran (100 g) was roasted in an electric oven equipped with a stirrer and a temperature controller. Rice bran was roasted with constant stirring at $160,170,180,190$ and $200{ }^{\circ} \mathrm{C}$ for $5,10,15,25$, and $35 \mathrm{~min}$, respectively. The roasted rice bran, after cooling to ambient temperature, was subjected to oil extraction following procedure described by Mamidipally and Liu (2004) and $\mathrm{Hu}$ et al. (1996). Each sample was soaked in $n$-hexane in a ratio of 1:5. The mixture was stirred for $45 \mathrm{~min}$ at ambient temperature $\left(29^{\circ} \mathrm{C} \pm 2 \mathrm{C}\right)^{\circ}$ and was subsequently, left to stand for $48 \mathrm{~h}$ at room temperature. It was then filtered through filter paper (Whatman No. 4) and the hexane residues in the oil solvent phase (filtrate) was evaporated in a rotary evaporator followed by drying in a hot-air oven at $100{ }^{\circ} \mathrm{C}$ for $30 \mathrm{~min}$ to eliminate residual $n$-hexane (Hanmoungjai et al., 2001) and placed in desiccator for moisture removal. Unroasted rice bran was prepared by the same procedure as described above. The extracted rice bran oil was filtered to remove particles. The oil percentage per gram of sample was calculatd.

Determination of free fatty acid. AOCS (2004) official method Ca $5 \mathrm{a}-40$ was used for the determination of free fatty acid content of oil. Oil samples of about $7.05 \mathrm{~g}$ in duplicate were put in $250 \mathrm{~mL}$ flask with addition of 50 $\mathrm{mL}$ neutralized alcohol. The mixture was titrated with $0.25 \mathrm{~N} \mathrm{NaOH}$ with vigorous shaking until faint pink colour appears and persists for $60 \mathrm{sec}$. Quantity of 0.25 $\mathrm{N} \mathrm{NaOH}(\mathrm{mL})$ used in the titration corresponding to the percentage of free fatty acids (FFA) as oleic acid may be calculated using the following equation:

FFA $(\%)=\frac{(\mathrm{V}-\mathrm{B}) \times \mathrm{Nf} \times 28}{\mathrm{~W}}$

Where:

$\mathrm{FFA}=$ free fatty acids

$\mathrm{V}=$ volume of the $\mathrm{NaOH}$ consumed (mL.)

$\mathrm{B}=$ volume of $\mathrm{NaOH}$ consumed during blank titration (mL.)

$\mathrm{W}=$ weight of oil sample $(\mathrm{g})$

$\mathrm{Nf}=$ normality of $\mathrm{NaOH}$ factor

Determination of peroxide value. The extracted oil was analyzed for peroxide value by the method recommended by AOCS (2004). Oil sample (5.00 \pm $0.05 \mathrm{~g}$ ) was weighed in $250 \mathrm{~mL}$ glass stoppered flask in duplicate. $\mathrm{HOAC}-\mathrm{CHCl}_{3}(30 \mathrm{~mL})$ was added and swirled to dissolve. Saturated potassium iodide solution $(0.5 \mathrm{~mL})$ was added with occasional shaking for $1 \mathrm{~min}$ and $30 \mathrm{~mL}$ distilled water was added. The solution was titrated slowly with $0.1 \mathrm{~N}$ sodium thiosulphate $\left(\mathrm{Na}_{2} \mathrm{~S}_{2} \mathrm{O}_{3}\right)$ and vigorously shaken until yellow colour disappears. Then $0.5 \mathrm{~mL}, 1 \%$ starch solution was added and titration was continued until blue colour just disappeared. Blank titration was conducted and the value obtained was subtracted from that of the sample. Three replicates of the experiment were undertaken and mean values were recorded.

Peroxide value (milliequivalent peroxide / $\mathrm{kg}$ sample) $=$ $\frac{\mathrm{S} \times \mathrm{N} \times 1000}{\text { sample }(\mathrm{g})}$

Where:

$\mathrm{S}=\mathrm{mL} \mathrm{Na}_{2} \mathrm{~S}_{2} \mathrm{O}_{3}$ (sample value-blank value)

$\mathrm{N}=$ normality of $\mathrm{Na}_{2} \mathrm{~S}_{2} \mathrm{O}_{3}$ solution.

Determination of oil colour. The colour of oil was measured using a JENWAY colorimeter model type 6051 to measure absorbance at $540 \mathrm{~nm}$ wavelength (Tan et al., 2004).

\section{Results and Discussion}

The result of the effects of roasting temperature and time on oil yield and quality are shown in Table 1. The percentage oil yield extracted from rice bran ranged between 11. 31-14.50\%. The maximum oil yield of 
Table 1. Effects of roasting temperature and time on oil yield, free fatty acid, peroxide value and colour

\begin{tabular}{llllll}
\hline \hline $\begin{array}{l}\text { Roasting } \\
\text { temp. }\left({ }^{\circ} \mathrm{C}\right)\end{array}$ & $\begin{array}{l}\text { Roasting } \\
\text { time }(\mathrm{min})\end{array}$ & Oil yield (\%) & FFA (\%) & Colour (abs) & PV (meq/kg) \\
\hline 160.00 & 15.00 & 11.31 & 8.51 & 1.51 & 13.75 \\
170.00 & 10.00 & 12.59 & 8.90 & 1.53 & 11.85 \\
170.00 & 25.00 & 12.68 & 11.80 & 1.53 & 10.20 \\
180.00 & 5.00 & 13.08 & 10.60 & 1.54 & 8.50 \\
180.00 & 15.00 & 14.45 & 7.10 & 1.54 & 8.25 \\
180.00 & 35.00 & 14.24 & 12.75 & 1.58 & 9.30 \\
190.00 & 10.00 & 12.71 & 9.60 & 1.55 & 9.10 \\
190.00 & 25.00 & 14.33 & 7.20 & 1.57 & 9.15 \\
200.00 & 15.00 & 14.50 & 5.80 & 1.58 & 8.50 \\
\hline \hline
\end{tabular}

$14.50 \%$ was achieved at roasting temperature $200{ }^{\circ} \mathrm{C}$ and roasting time of $15 \mathrm{~min}$. Minimum oil yield recorded was $11.31 \%$ at $160{ }^{\circ} \mathrm{C}$ roasting temperature and roasting time of $15 \mathrm{~min}$. On the average, $13.67 \pm 1.06 \%$ of oil was recovered from rice bran. The oil recovered was within the range (10.0-26.0\%) reported by Prabhakar and Venkatesh (1986). The difference in the results obtained may be traced to the method of oil extraction, rice varieties and type of organic solvent used. Variety and environmental variability influence chemical composition of rice bran (Luh et al., 1991). Rice bran oil yield increased with increase in roasting temperature and time. The oil percentage for unroasted rice bran was low as compared to that of the roasted rice bran. A statistical analysis of the data (Table 2) showed that mean value of oil yield significantly increased as roasting temperature and time increased.

The free fatty acid value of oil ranged between 5.80 $12.75 \%$ oleic acid. The maximum free fatty acid value determined in rice bran oil was $12.75 \%$ at roasting temperature $180^{\circ} \mathrm{C}$ and at roasting time of $35 \mathrm{~min}$. At

Table 2. Summary of results of the experiments

\begin{tabular}{lllll}
\hline \hline Factors & $\begin{array}{l}\text { Oil } \\
\text { yield } \\
(\%)\end{array}$ & $\begin{array}{l}\text { Free } \\
\text { fatty acid } \\
(\%)\end{array}$ & $\begin{array}{l}\text { Peroxide } \\
\text { value } \\
(\mathrm{meq} / \mathrm{kg})\end{array}$ & $\begin{array}{l}\text { Colour } \\
(\mathrm{abs})\end{array}$ \\
\hline $\mathrm{N}$ & 13 & 13 & 13 & 13 \\
$\mathrm{df}$ & 12 & 12 & 12 & 12 \\
Minimum & 11.31 & 5.80 & 8.25 & 1.51 \\
Maximum & 14.50 & 12.75 & 13.75 & 1.58 \\
Mean & 13.67 & 8.48 & 9.35 & 1.54 \\
S.D. & 1.06 & 2.11 & 1.68 & 0.02 \\
\hline \hline
\end{tabular}

$\mathrm{N}=$ number of experiments run; $\mathrm{df}=$ degree of freedom. roasting temperature $200{ }^{\circ} \mathrm{C}$ and roasting time of $15 \mathrm{~min}$, the free fatty acid value was $5.80 \%$, the minimum. The free fatty acid values had mean of $8.48 \pm 2.11 \%$. The results showed that free fatty acid values begin to decrease as the temperature rises. This means that lipase, which initiates rapid hydrolytic deterioration in rice bran oil is deactivated to the maximum level. Free fatty acid value starts increasing at roasting temperature $180{ }^{\circ} \mathrm{C}$ and roasting time of $35 \mathrm{~min}$, which can be attributed to the prolong roasting duration (35 $\mathrm{min}$ ) which may accelerate hydrolysis in rice bran oil. This is in agreement with the findings of Rai et al. (1990) that increase of free fatty acids depends on time factor even after stabilization.

Peroxide value (PV) is one of the most widely used chemical tests for determination of fat and oil quality. Preferences for fat and oil products with fresh bland flavours and odours require quality and rancidity evaluations during development and after processing. $\mathrm{PV}$ is a measure of oxidation and rancidity in its early stage and shows good correlation with organoleptic flavour scores (O'Brien, 2008). The lower the peroxide value, the better the oil quality. It is known that factors such as temperature, light, moisture, metals, and oxygen affect rate of oxidation. This is a major cause of their deterioration (Salunkhe et al. 1992). The peroxide value determined at different roasting temperature and time for rice bran oil was minimum $(8.25 \mathrm{meq} / \mathrm{kg})$ at roasting temperature $180^{\circ} \mathrm{C}$ and roasting time $15 \mathrm{~min}$ and maximum $(13.75 \mathrm{meq} / \mathrm{kg})$ at roasting temperature $160{ }^{\circ} \mathrm{C}$ and roasting time $15 \mathrm{~min}$. The oil had mean peroxide value of $9.35 \pm 1.68 \mathrm{meq} / \mathrm{kg}$. The lowest peroxide value of $8.25 \mathrm{meq} / \mathrm{kg}$ was lower than $10.6,9.1$, and $8.5 \mathrm{meq} /$ $\mathrm{kg}$ reported by Tan et al. (2002) for grape seed, 
sunflower, and olive oils, respectively, but higher than 0.82 and $6.68 \mathrm{meq} / \mathrm{kg}$ reported by the same authors for refined-bleached-deodourized palm olein and canola oils, respectively.

The colour intensity of rice bran oil as rated by colorimeter ranged from 1.51 to 1.58 abs. The statistical analysis of oil colour (Table 2) showed that it has mean of $1.55 \pm 0.02$ abs. It was observed that rice bran oil colour was a function of extraction time and temperature. It becomes darker with increase of extraction time and temperature, especially at high temperatures. This phenomenon might be due to the formation of oxidative materials including polymers and other oil-soluble products undergoing the Millard reactions (Liu and Mamidipally, 2005) and pyrolysis reaction. The impurities can be removed by a series of oil refining processes.

\section{Conclusion}

The analysis of the results relating to the yield and quality of extracted oil showed that individual effects of roasting temperature and time, as well as their interactive effects were significant. The optimum process parameters for the extraction of high yield, and good quality rice bran oil were roasting temperature $200{ }^{\circ} \mathrm{C}$ and roasting time $15 \mathrm{~min}$, which gave $14.45 \%$ oil yield, $5.80 \%$ free fatty acid, $8.25 \mathrm{meq} / \mathrm{kg}$ peroxide value and 1.51 abs colour. It was understood that the conventional solvent extraction methods, such as hexane at ambient temperature, could not completely stabilize rice bran oil and the results showed that total free fatty acids concentration increased in the course of rice bran oil storage.

\section{References}

AOCS. 2004. The Official Methods and Recommended Practices of the American Oil Chemists Society, $4^{\text {th }}$ edition, American Oil Chemists Society, pp. 12. Champaign, IL, USA.

Devi, R., Arumughan, C. 2007. Phytochemical characterization of defatted rice bran oil and optimization of a process for its extraction and enrichment. Bioresource Technology, 98: 3037-3043.

Enochian, R.V., Saunders, R.M., Schultz, W.G., Beagle, E.C., Crowley, P.R. 1981. Stabilization of rice bran with extruder cookers and recovery of edible oil; a preliminary analysis of operational and financial feasibility, USDA, Marketing Research Report No.1120.
Goffman, F.D., Pinson, S., Bergman, C. 2003. Genetic diversity of lipid content and fatty acid profile in rice bran. Journal of American Oil Chemists' Society, 80: 485-490.

Hanmoungjai, P., Pyle, D.L., Niranjan, K. 2001. Enzymatic process for extracting oil and protein from rice bran. Journal of American Oil Chemists' Society, 78: 817-821.

Hargrove, K.L. Jr. 1994. Processing and utilization of rice bran in the United States. In: Rice Science and Technology, W. E. Marshall and J. I. Wadsworth (eds.), pp. 381-404. Marcel Dekker Inc., New York, USA.

Hu, W., Wells, J.H., Shin, T.S., Godber, J.S. 1996. Comparison of isopropanol and hexane for extraction of vitamin $\mathrm{E}$ and oryzanol from stabilized rice bran. Journal of American Oil Chemists 'Society, 73: 1653 1656.

Liu, S.X., Mamidipally, P.K. 2005. Quality comparison of rice bran oil extracted with d-limonene and hexane. Cereal Chemistry, 82: 209-215.

Luh, B.S., Barber, S., deBarger, C.B. 1991. In: Rice Utilization, Vol. II., B.S. Luh, (ed.) AVI Book, Van Nostrand Reinhold, New York, USA.

Luh, B.S. 1980. Rice: Production and Utilization. AVI Publishing Co. Inc., New York, USA.

Mamidipally, P.K., Liu, S.X. 2004. First approach on rice bran oil extraction using limonene. European Journal of Lipid Science and Technology, 106: 122-125.

McCaskill, D. R., Zhang, F. 1999. Use of rice bran oil in foods. Food Technology, 53: 50-53.

Most, M.M., Tulley, R., Morales, S., Lefevre, M. 2005. Rice bran oil, not fiber, lowers cholesterol in humans. The American Journal of Clinical Nutrition, 8: 64-80.

O'Brien, R.D. 2008. Fats and Oils, Formulating and Processing for Application, pp. 206-207, Technical Publishing, Company, Inc. Lancaster, USA.

Prabhakar, J.V., Venkatesh, K.V.L. 1986. A simple chemical method for stabilization of rice bran. Journal of the American Oil Chemists' Society, 63: 644-646.

Rai, M.Y., Ahmad, M., Saeed, M.A. 1990. Edible rice bran oil. Pakistan Journal of Scientific and Industrial Research, 33: 410-412.

Salunkhe, D.K., Chavan, J.K., Adsule, R.N., Kadam, S.S. 1992. World Oilseeds: Chemistry, Technology and Utilization, pp. 424-448, Van Nostrand Reinhold, New York, USA. 
Saunders, R.M. 1986. Rice bran composition and potential food uses. Food Reviews International, 1: 465-495.

Sereewatthanawut, I., Prapintip, S., Watchirauruji, K., Goto, M., Sasaki, M., Shotipruk, A. 2008. Extraction of protein and amino acids from deoiled rice bran by subcritical water hydrolysis. Bioresource Technology, 99: 555-561.

Sun, G.X., Williams, P.N., Carey, A.M., Zhu, Y.G., Deacon, C., Raab, A., Feldmann, J., Islam, R.M., Meharg, A.A. 2008. Inorganic arsenic in rice bran and its products are an order of magnitude higher than in bulk grain. Environmental Science and Technology, 42: 7542-7546.

Tan, Y.A., Ainie, K., Lee, C.K., Low, K.W., Low, K.S. 2004. Comparative evaluation of palm oil colour measurement using a prototype colorimeter. Journal of American Oil Chemists' Society, 81: 733-736.

Tan, C.P., Man, Y.B., Selamat, J., Yusoff, M.S.A. 2002. Comparative studies of oxidative stability of edible oils by differential scanning calorimetry and oxidative stability index methods. Food Chemistry, 76: 385-389.

Tao, J., Rao, R., Liuzzo, J. 1993. Microwave heating for rice bran stabilization. The Journal of Microwave Power and Electromagnetic Energy, 28: $156-164$.

Westphal, S., Gekeler, G.H., Dierkes, J., Wieland, H., Luley, C. 2002. A free fatty acid tolerance test identifies patients with coronary artery disease among individuals with a low coronary risk profile. Heart and Vessels, 16: 79-85.

Yoshida, H., Takagi, S., Mitsuhashi, S. 1999. Tocopherol distribution and oxidative stability of oils prepared from the hypocotyl of soybeans roasted in a microwave oven. Journal of American Oil Chemists'Society, 76: 915-920.

Zullaikah, S., Lai, C.C., Vali, S.R., Ju, Y.H. 2005. A two-step acid-catalyzed process for the production of biodiesel from rice bran oil. Bioresource Technology, 96: 1889-1896. 